\title{
A study on effect of tramadol hydrochloride on both mother and newborn in using labor pain
}

\author{
Asha Rani K. N. M.* \\ Department of Obstetrics \& Gynaecology, VIMS, Bellary, Karnataka, India \\ Received: 21 January 2016 \\ Accepted: 04 February 2016 \\ *Correspondence: \\ Dr. Asha Rani K.N.M., \\ E-mail: drasharani689@gmail.com \\ Copyright: (C) the author(s), publisher and licensee Medip Academy. This is an open-access article distributed under \\ the terms of the Creative Commons Attribution Non-Commercial License, which permits unrestricted non-commercial \\ use, distribution, and reproduction in any medium, provided the original work is properly cited.
}

\begin{abstract}
Background: The analgesic efficacy of intramuscular opioids versus epidural analgesia in labor and concluded that the analgesic efficacy and maternal satisfaction is better with epidural analgesia than with opioids. Hence in developing nations, where availability of facilities is the main limiting factor, intramuscular opioids can be considered suitable alternatives.

Methods: A 200 primigravid women presenting with full term pregnancy at a tertiary care center constituted the study subjects.

Results: Birth weights of babies' shows maximum number (65\%) of babies have birth weight of 2.5 to $2.9 \mathrm{Kg}$. About $28.5 \%$ have birth weight between 3 to $3.4 \mathrm{Kg}, 6.5 \%$ of babies' have birth weight of $2-2.4 \mathrm{Kg}$.

Conclusions: This Drug has no adverse effects in the mothers/ on to newborn.
\end{abstract}

Keywords: Tramadol, Labor pain, Maternal and fetal outcome

\section{INTRODUCTION}

The most important consideration in pregnancy is that there are two individuals receiving treatment - mother and baby. Anesthetic requirements in the peripartum period include long periods of constant pain relief and increased depth of analgesia might be needed as labour progressed and pain increases. ${ }^{1}$ With no universally accepted and applicable analgesic agent for use during childbirth, the search for a better drug continues.

Jain S, Arga VK, Gopala S, Jain V studied the analgesic efficacy of intramuscular opioids versus epidural analgesia in labour and concluded that the analgesic efficacy and maternal satisfaction is better with epidural analgesia than with opioids. Hence in developing nations, where availability of facilities is the main limiting factor, intramuscular opioids can be considered suitable alternatives. $^{2}$
Keskin et al compared the analgesic efficacy and adverse effects of tramadol and pethidine in labour and concluded that pethidine seems to be a better alternative than tramadol in obstetric analgesia because of its superiority in analgesic efficacy and low incidence of maternal side effects.

Fieni S et al evaluated the efficacy and tolerability of the two opioids usually used today in parenteral analgesia to reduce pain during labour - tramadol and meperidine and concluded that tramadol in accordance to the obtained in literature gives an analogous analgesic effect with better tolerability for the absence of collateral effects on the mother fetus and newborn. ${ }^{4}$

Long Jianjing and Yue Yun evaluated the safety and analgesic efficacy of patient controlled intravenous analgesia (PCIA) with tramadol and to compare its benefits and risk with combined spinal - epidural analgesia (CSEA) + patient controlled epidural analgesia PCEA and concluded that PCIA with tramadol is now a 
useful alternative when patients are not candidates for CSEA for labour or do not want to have a neuraxial block anaesthesia. However sometimes it may not provide satisfactory analgesic effect. ${ }^{5}$

Thakur Ratna, Patidar Rekha compared the effect of transcutaneous electrical nerve stimulation (TENS) with $100 \mathrm{mg}$ IM tramadol for pain relief in labour and concluded that pain relief in labour with TENS is as good as that with tramadol. TENS has hardly any side effects. ${ }^{6}$

Bitsch $\mathrm{M}$ et al used parenteral analgesia with tramadol in 23 normal deliveries. The results were compared to another group, which received pethidine as a labour analgesia. He concluded that both the medications exerted identical analgesic effects. ${ }^{7}$

No adverse effects were observed with tramadol concerning the follow-up of labour / the newborn. Thus, he recommended tramadol for obstetrical analgesia since it does not exert inhibitory effects on the respiration centre.

Hussein P, Kubista, Egarter C in 1987 conducted a prospective randomized comparative study of tramadol $100 \mathrm{mg}$ with pethidine $100 \mathrm{mg}$ on 40 women asking for pain relief during labour. The duration of labour was slightly but not significantly shorter in the pethidine group. The results of the study seem to establish an analgesic effect of tramadol similar to pethidine but with less side effects. ${ }^{8}$

\section{METHODS}

A 200 primigravid women presenting with full term pregnancy at a Tertiary care center constituted the study subjects

\section{Inclusion criteria}

All primigravid women presenting with:

- Full term pregnancy

- Vertex presentation

- Singleton live fetus

- In active phase of labour with engaged head for vaginal delivery.

\section{Criteria for active labour}

- 3-5 cm of cervical dilatation

- Fully effaced cervix

- Good uterine contractions i.e., contractions lasting for at least 25-30 seconds and 3 such contractions in a period of $10 \mathrm{~min}$.

\section{Exclusion criteria}

- Parturients with any associated history of medical disorders.
- Any associated obstetrical complication with multiple gestation, APH, placenta previa, IUGR, CPD, epilepsy, psychiatric disorders

- History of hypersensitivity to drug.

Once the patient is in established active phase of labour i.e., $\geq 3 \mathrm{cms}$ dilatation, full effacement with good uterine contractions, vital signs recorded and primary investigations done and pain score was noted before administering the drug. Injection tramadol $100 \mathrm{mg}$ IM was given as a single dose depending on condition of the patient i.e., $2 \mathrm{mg} / \mathrm{Kg} /$ body weight. Pulse rate, respiratory rate, blood pressure, FHR were recorded. Patient was advised to inform as soon as pain begins to decrease in intensity or even if there is no pain relief at all. Partogram was marked to assess the progress of labour.

The following observations were recorded:

1. Onset of action of the drug

2. Drug side effects, change in vital parameters at first every $30 \mathrm{~min}$, and then at hourly were monitored.

3. FHR monitoring was done clinically and any variability noted.

4. Progress of labour was monitored clinically.

5. Assessment of analgesia was done hourly by scoring system, injection repeated every 3 hours, not exceeding $400 \mathrm{mg} / \mathrm{day}$.

6. Patient level of consciousness, alertness, psychological disturbances was judged.

7. The duration of labour, degree of pain relief in first and $2^{\text {nd }}$ stage, the total dose of tramadol given, the mode of delivery and recovery time in each patient was noted and recorded.

8. Apgar score at 1 and 5 minutes interval after delivery of neonate was recorded.

9. Any complication during the course of labour was recorded. Patient was observed for 2 hours after delivery and was shifted to the ward if there were no complications.

\section{RESULTS}

Table 1: Duration of stage of labour.

\begin{tabular}{|llll|}
\hline $\begin{array}{l}\text { Stage of } \\
\text { duration }\end{array}$ & $\begin{array}{l}\text { Mean } \\
\text { duration }\end{array}$ & $\begin{array}{l}95 \% \\
\text { SD of } \\
\text { duration } \\
\text { Confidence } \\
\text { interval of } \\
\text { mean } \\
\text { duration }\end{array}$ \\
\hline $\begin{array}{l}\text { Stage I } \\
\text { (Minutes/hr.) }\end{array}$ & $\begin{array}{l}172.375 / \\
\text { Stage II }\end{array}$ & $\begin{array}{l}69.378 / \\
\text { (Minutes/hr.) }\end{array}$ & $\begin{array}{l}162.76, \\
181.98 /(3.41, \\
4.03)\end{array}$ \\
\hline $\begin{array}{l}\text { Stage III } \\
\text { (Minutes/hr.) }\end{array}$ & $\begin{array}{l}23.56 \\
\text { (M.29/ }\end{array}$ & $11.38 /$ & $\begin{array}{l}18,88,2204 / \\
(36.31,21.61)\end{array}$ \\
\hline & & $2.310 /$ & $\begin{array}{l}5.27,5.91 / \\
(5.79,6.78)\end{array}$ \\
\hline
\end{tabular}


Mean duration of Labor of Stage I is 3.72 hours with $95 \%$ confidence Interval of 3.41 hours and 4.03 hours.

Mean duration of labor of stage II is 20.46 minutes with $95 \%$ confidence Interval of 18.88 minutes and 22.04 minutes.

Mean duration of labor of stage III in minutes is 5.59 minutes with $95 \%$ confidence Interval of 5.27 minutes and 5.91minutes.

Table 2: Total duration of labour.

\begin{tabular}{|l|l|l|}
\hline $\begin{array}{l}\text { Total duration (in } \\
\text { Minutes/hr.) }\end{array}$ & $\begin{array}{l}\text { No of } \\
\text { women }\end{array}$ & Percentage \\
\hline $0-180 / 0-3$ & 78 & 39.00 \\
\hline $180-360 / 3-6$ & 122 & 61.00 \\
\hline Total & 200 & 100 \\
\hline
\end{tabular}

Maximum patients i.e. $122(61 \%)$ had total duration of labor between 3 to 6 hours and 78 patients i.e. $39 \%$ of women had total duration of labor less than 3 hours.

Table 3: Distribution of newborn babies by their APGAR score at birth.

\begin{tabular}{|lll|}
\hline Apgar score & $1^{3}$ & 5 \\
\hline $3-5$ & 179 & -- \\
\hline $6-7$ & 21 & 6 \\
\hline $8-10$ & -- & 194 \\
\hline & 200 & 200 \\
\hline
\end{tabular}

The Apgar score at 1 minute is 5.05 with $95 \%$ CI of (4.96.5.14).

The Mean APGAR score at 5 minutes is 8.77 with $95 \%$ CI of $(8.69,8.84)$.
Table 4: Mean APGAR score of neonates.

\begin{tabular}{|llll|}
$\begin{array}{l}\text { Time } \\
\text { (in } \\
\text { minutes) }\end{array}$ & $\begin{array}{l}\text { Mean } \\
\text { apgar score }\end{array}$ & $\begin{array}{l}\text { SD of } \\
\text { apgar } \\
\text { score }\end{array}$ & $\begin{array}{l}95 \% \text { CI of } \\
\text { apgar score }\end{array}$ \\
\hline 01 & 5.05 & 0.60 & $(4.96,5.13)$ \\
\hline 05 & 8.77 & 0.58 & $(8.68,8.85)$ \\
\hline
\end{tabular}

Table 5: Showing the birth weights $(\mathrm{kg})$ of babies.

\begin{tabular}{|lll|}
\hline Birth weight $(\mathrm{Kg})$ & No. of births & Percentage \\
\hline $2.00-2.40$ & 13 & 6.5 \\
\hline $2.50-2.90$ & 130 & 65.0 \\
\hline $3.00-3.40$ & 57 & 28.5 \\
\hline Total & 200 & 100 \\
\hline $\begin{array}{l}\text { Mean birth weight of } \\
\text { 200 births }\end{array}$ & $2.86 \mathrm{Kg}$ \\
\hline SD of Birth weight & $0.2753 \mathrm{Kg}$ & \\
\hline $\begin{array}{l}\text { 95\% CI for birth } \\
\text { weight }\end{array}$ & $\begin{array}{l}(2.822 \mathrm{Kg}, \\
2.898 \mathrm{Kg})\end{array}$ \\
\hline
\end{tabular}

Birth weights of babies' shows maximum number $(65 \%)$ of babies have birth weight of 2.5 to $2.9 \mathrm{Kg}$. About $28.5 \%$ have birth weight between 3 to $3.4 \mathrm{Kg}, 6.5 \%$ of babies' have birth weight of $2-2.4 \mathrm{Kg}$.

\section{DISCUSSION}

In the present study, 6 of the woman had minimum side effects like nausea and vomiting. There was no significant change in the vital parameters like pulse rate, respiratory rate, blood pressure, thus proving safety of tramadol as an obstetric analgesic. This observation is at par with the other studies which also suggested a superior safety profile of tramadol.

Table 6: Comparative analgesic of neonatal outcome.

\begin{tabular}{|lllllll|}
\hline $\begin{array}{l}\text { Neonatal } \\
\text { condition }\end{array}$ & $\begin{array}{l}\text { Prasert-sawat } \\
\text { CTR }^{9}\end{array}$ & $\begin{array}{l}\text { Sarkar } \\
\text { IJOG }^{10}\end{array}$ & Bajaj JP & $\begin{array}{l}\text { Hussein gerburtsh, } \\
\text { perinatol }^{12}\end{array}$ & $\begin{array}{l}\text { Thakur } \\
\text { ratna }^{13}\end{array}$ & $\begin{array}{l}\text { Present } \\
\text { study }^{\text {11 }}\end{array}$ \\
\hline Good & 100 & 95 & 100 & 98 & 98 & 200 \\
\hline Distress & -- & 5 & -- & 2 & 2 & - \\
\hline Total & 100 & 100 & 100 & 100 & 100 & 200 \\
\hline
\end{tabular}

Table 7: Comparative study.

\begin{tabular}{|c|c|c|c|}
\hline $\begin{array}{l}\text { Mean } \\
\text { APGAR } \\
\text { score }\end{array}$ & $\begin{array}{l}\text { Thakur } \\
\text { ratna }^{13}\end{array}$ & $\begin{array}{l}\text { Meena jyoti, } \\
\text { Singhal prabha } \\
\text { et al }\end{array}$ & $\begin{array}{l}\text { Present } \\
\text { study }\end{array}$ \\
\hline 1 minute & $7.02 \pm 0.60$ & $>7.00$ & 5.05 \\
\hline 5 minutes & $9.05 \pm 0.88$ & $>7.00$ & 8.77 \\
\hline
\end{tabular}

The difference is not statistically significant. Neonatal condition at delivery, assessed by Apgar score was as good as to compare with the other standard studies of the series. Incidence of fetal distress was also decreased present study is comparable with Prasertsawat (0\%), Bajaj (0\%), Hussein (2\%) and Thakur Ratna (2\%).

In the present study, 200 primi parae in the active phase of labor were given injection tramadol $100 \mathrm{mg}$ as a single dose at the onset of active labor. The youngest patient was 18 years of age and eldest 30 years, $(60.5 \%)$ patients were in the 20-24 years age group. The Bishop's score at the time of administration of tramadol ranged between 5- 
11. All patients were given $100 \mathrm{mg}$ tramadol each intramuscularly. 20 patients needed a second dose, $100 \%$ patients had vaginal delivery.

It was observed that the more favourable the Bishops score, the shorter the injection delivery internal. The shortest injection delivery interval was $60 \mathrm{~min}$ and longest $360 \mathrm{~min}$. However, $61 \%$ of subjects delivered between 3-6 hours after administration of the drug. This observation was made by Thakur Ratna, Hussein et al in their studies.

In the present study, all of the subjects had pain relief with tramadol. Of patients who experienced relief from pain $100 \%$ had moderate relief both in the $1^{\text {st }}$ and $2^{\text {nd }}$ stages of labour, thus establishing that the efficacy of tramadol for relief of labour pain was good as also noted by Thakur Ratna, Jain S, Bajaj in their study. Most of the 200 newborn had good Apgar score ranging from 7-9, comparable to Baja et al study, who observed Apgar score of $>8$ in all neonates of tramadol group.

Minimum side effects of tramadol were seen in our patients with no significant change in maternal vital parameters thus proving safety of tramadol as an obstetric analgesic. This observation is in par with the other studies which also suggested a superior safety profile, Suvonnakote et al, Prasertsawat et al who reported minimal side effects in women receiving tramadol.

Programming of labour is simple, easy and effective method for painless and safe delivery. The analgesia produced is quite effective and overall duration of labor is significantly reduced. Blood loss in third stage is also significantly reduced. Maternal side effects are minor without any fetal or neonatal respiratory depression.

\section{CONCLUSIONS}

The maternal psychological attitude was improved and better tolerance instituted in these mothers with no adverse effects in the mothers/ on to newborn.

Funding: No funding sources

Conflict of interest: None declared

Ethical approval: The study was approved by the Institutional Ethics Committee

\section{REFERENCES}

1. Lan Lee TS, Leang T. Pain relief in labour - The Management of Labour. S. Arulkumaran, Ratnam SS, Bhaskar Rao Ed.
2. Jain S. Analgesic efficacy of intramuscular opoids versus epidural analgesia in labour. Int. $\mathbf{J}$ of Gynecology \& Obstet. 2003;83(1):19-27.

3. Keskin HL, Keskin A. Pethidine versus tramadol for pain relief during labour. International Journal of Gynecol \& Obstet. 2003;82(1):11-6.

4. Fieni S, Angeri Ct, Kaihura. Evaluation of peripartum effects of 2 analgesics - Meperidine and tramadol used in labour. Acta Biomedical de Pateneo Parmensa Supplement. 2000;71:397-400.

5. Jianjing L, Yun Y. Patient controlled intravenous analgesia with tramadol for labour pain relief. Chin. Med. J. 2003;116(11):1752-55.

6. Sharma UR, Verma RS. Use of tramadol as an analgesic in normal and abnormal labour. $\mathrm{J}$ of Obstet \& Gynecol of India. 1997;67-8.

7. Bitsch MEJ, Hary J, Lippach G, Rindt W. Obstetrical analgesia with tramadol. Fortschr Med. 1980;24:98 (16):632-4.

8. Mathia C, Coluzzi F. Tramadol focus on musculoskeletal and neuropathic pain. Minerva Anesthesiol, 2005;71(10):565-84.

9. Pratak OP, Herabutya Y, Chatura C. Obstetric analgesia: Comparison between tramadol, morphine and pethidine. Curr Ther Res. 1986;40(6):1022-8.

10. Sarkar B, Mukhopadhyay AK. Tramadol hydrochloride in dysfunctional labour a clinical trial. The Journal of Obst and Gyn of India. 1997;47(1):42-7.

11. Bajaj P, Meena R, Prasad R. Intravenous tramadol for labour analgesia. The Indian Practitioner. 1997;50(12):1051-4.

12. Husshein P, Egarter K. Obstetrical analgesia with tramadol - Results of a prospective randomized comparative study with pethidine. Z Geburtshilfe. Perinatol. 1987;191(6):234-7.

13. Thakur R, Patidar R. Comparative study of transcutaneous electrical nerve stimulation (TENS) and tramadol hydrochloride for pain relief in labor. $\mathrm{J}$ Obstet Gynecol Ind. 2004;54(4):346-50.

14. Meena J, Singhal P, Choudhary D. Programed labor, J Obstet Gynecol India. 2006;56(1):53-5.

Cite this article as: Asha Rani KNM. A study on effect of tramadol hydrochloride on both mother and newborn in using labor pain. Int J Reprod Contracept Obstet Gynecol 2016;5:633-6. 